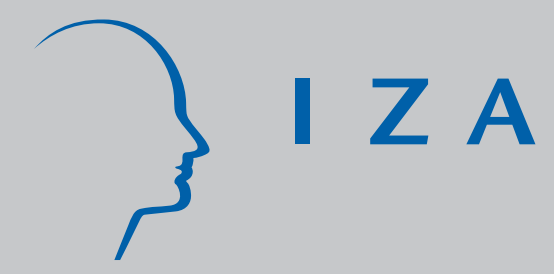

IZA DP No. 3147

The Employees of Native and Immigrant Self-Employed

Pernilla Andersson

Eskil Wadensjö

November 2007 


\title{
The Employees of Native and Immigrant Self-Employed
}

\author{
Pernilla Andersson \\ SOFI, Stockholm University, SULCIS \\ Eskil Wadensjö \\ SOFI, Stockholm University, SULCIS \\ and IZA
}

Discussion Paper No. 3147

November 2007

\author{
IZA \\ P.O. Box 7240 \\ 53072 Bonn \\ Germany \\ Phone: +49-228-3894-0 \\ Fax: +49-228-3894-180 \\ E-mail: iza@iza.org
}

Any opinions expressed here are those of the author(s) and not those of the institute. Research disseminated by IZA may include views on policy, but the institute itself takes no institutional policy positions.

The Institute for the Study of Labor (IZA) in Bonn is a local and virtual international research center and a place of communication between science, politics and business. IZA is an independent nonprofit company supported by Deutsche Post World Net. The center is associated with the University of Bonn and offers a stimulating research environment through its research networks, research support, and visitors and doctoral programs. IZA engages in (i) original and internationally competitive research in all fields of labor economics, (ii) development of policy concepts, and (iii) dissemination of research results and concepts to the interested public.

IZA Discussion Papers often represent preliminary work and are circulated to encourage discussion. Citation of such a paper should account for its provisional character. A revised version may be available directly from the author. 
IZA Discussion Paper No. 3147

November 2007

\section{ABSTRACT \\ The Employees of Native and Immigrant Self-Employed}

Using unique register data for Sweden we can match self-employed persons to their employees. We analyze the national composition of the employees and ask if self-employed immigrants mainly employ workers from their home region and if self-employed natives mainly employ native workers. We find that both natives and immigrants are more likely to employ co-nationals than to employ workers with a different national background. We also analyze which factors influence the propensity to hire co-nationals. For immigrants we find that living in a municipality with a high share of co-nationals decreases the probability of employing natives, while the probability that natives employ immigrants increases with the immigrant share in the municipality. We find that the probability for immigrants to hire native workers increases with time spent in Sweden. This result points to that the proximity to people from the same region and possibly also one's network plays an important role for the employment decisions for both self-employed natives and immigrants.

JEL Classification: J15, J61

Keywords: $\quad$ self-employment, immigrants, networks

Corresponding author:

Eskil Wadensjö

Swedish Institute for Social Research

Stockholm University

SE 10691 Stockholm

Sweden

E-mail: Eskil.Wadensjo@sofi.su.se

\footnotetext{
* We would like to thank participants, especially the discussant on our paper Donald Parsons, in the SOLE conference in Chicago May 2007 for helpful comments on an earlier version of the paper. We would also like to thank the Swedish Council for Working Life and Social Research (FAS) and the Swedish Research Council for grants to the project.
} 


\section{Introduction}

Many believe that employers mainly hire people who are similar to themselves. There is however limited empirical evidence of this since it is often difficult to get data on the recruitment process within firms. One way in which we can investigate this is to analyze the employees of the self-employed. In most cases the self-employed are owners of fairly small firms and we can therefore assume that the self-employed individual himself or herself who decides who to hire. We use unique Swedish data for 1998 in which all individuals in Sweden are included. We have identified the self-employed individuals in the data and have information on a large set of individual characteristics of the self-employed. Using the identification number of the firm, we can match the self-employed person to his or her employees.

It is interesting to analyze the composition of workers in a firm and how their characteristics are related to those of the self-employed person, in several dimensions: gender, age, education, and country of origin. In this paper we will focus on the composition of workers by country of origin. This is a particularly interesting issue since a high share of employed non-Western immigrants work as self-employed. The recruitment pattern of native employers, i.e. in this case self-employed natives, is discussed in the context of labour market discrimination (see for example Carlsson and Rooth, 2007). A third reason for why this is an interesting topic is that there is a discussion about to what extent self-employment among immigrants can reduce unemployment in this group. This can happen in two ways (i) unemployed immigrants choose to become self-employed and (ii) they employ co-nationals who otherwise would have been unemployed.

The purpose of this paper is to analyze the composition of the employees of the selfemployed in terms of national background, and to discuss possible explanations for the pattern we find. 
There are several reasons as to why the self-employed would be more likely to employ people from the same region or country as themselves than to employ people with a different national background. One reason is that the self-employed will recruit from their networks and that their networks more likely consist of people similar to themselves. It does not have to be a question of preferences for employing a special group of employees, but of that information on potential employees is restricted by the network or the neighborhood one lives in. A second reason is that the self-employed have preferences for employing people with the same background and for that reason mainly hire people who are similar to themselves. A third reason is that the supply of potential workers is different for self-employed immigrants than for self-employed natives. Native workers may have preferences against working at workplaces run by a self-employed immigrant and hence only search for jobs at native firms and immigrant workers may have preferences against working at workplaces run by native self-employed. So even if the self-employed want to employ workers who have another national background than their own, there could be a shortage in the supply of such workers. A fourth reason is that some of the firms produce ethnic goods and services that people from the same country or region are more adept in such production.

We find that all groups of self-employed employ co-nationals to a much higher extent than they employ people from other regions. This is true both for self-employed natives and immigrants. The purpose of the paper is not to discriminate between the different reasons for employing mainly co-nationals but in a regression analysis we investigate which factors influence the probability of only employing co-nationals.

In a second set of regressions we estimate the probability of natives to employ at least one immigrant worker and the probability of immigrants to employ at least one native worker. Especially the analysis of immigrant firms who employ natives will reveal the characteristics 
of the self-employed immigrants who are integrated in the Swedish labour market to some extent.

For immigrants we find that living in a municipality with a high share of co-nationals decreases the probability of employing natives, while the probability that natives employ immigrants increases with the immigrant share in the municipality. We find that the probability for immigrants to hire native workers increases with time spent in Sweden. This result points to that the proximity to people from the same region and possibly also one's network play an important role for the employment decisions for both self-employed natives and immigrants.

This study contributes to our knowledge of the composition of the employees of the selfemployed and may enhance our understanding of the willingness of employers in relatively small firms to hire people who are different from themselves in terms of country of origin. This methodology can also be extended to study for example age, gender and educational similarities between the self-employed and their employees. Here, we focus on immigrant background.

The paper is organized as follows. In section two, earlier literature is reviewed and in section three the data is described and some descriptive statistics presented. In section four the regressions results are presented. Section five summarizes and concludes the paper. 


\section{Earlier Literature}

\subsection{Labour market segregation in Sweden among immigrants and natives}

Åslund and Nordström Skans (2005) study ethnic workplace segregation in Sweden where segregation is measured as exposure to colleagues at the workplace belonging to the same ethnic group. They find that there is substantial ethnic labour market segregation in Sweden. In particular immigrants are overexposed to others originating from the same region, but they are also overexposed to immigrants from other regions.

le Grand and Szulkin (2002) discuss occupational segregation between natives and immigrants in Sweden as one explanation for the native-immigrant income gap. They show that there exists occupational segregation, mainly between natives and non-Western immigrants, but that occupational segregation only explains part of the wage gap.

Earlier studies have found a high degree of ethnical segregation in the labour market. Immigrants tend to be employees at workplaces where a high share of co-ethnics works. In particular non-Western immigrants have the same occupations as many co-ethnics. The present paper adds another dimension to the analysis of labour market segregation in Sweden: To what extent do self-employed natives employ other natives, and to what extent do selfemployed immigrants employ other immigrants, in particular immigrants from the same region or country as themselves? Based on the previous results, we expect to find a high degree of segregation also at workplaces run by the self-employed.

\subsection{Recruitment and labour market segregation}

One explanation for why there is labour market segregation is that employers recruit workers through their networks and that these networks consist of people similar to themselves. For Sweden, Ekström (2001) finds that the most common way of recruiting new employees is via informal channels such as personal contacts and networks. She also finds that it is more 
common in small workplaces (1-9 employees) to use informal channels. Hence it seems likely that the self-employed who have few employees use their personal contacts to a high extent when recruiting workers.

Workers searching for a job also use their network. Mixed results have been found regarding the use of informal methods such as personal contacts and networks among natives and immigrants. Olli Segendorf (2005) finds that non-European immigrants, who went from unemployment to employment, were more likely to have received their job via informal contacts than were natives. Behtoui (2006a and 2006b) gets the opposite results. He finds that among those who did get a job, immigrants were less likely to have received it through personal contacts and networks than were natives.

A second explanation for segregated work places is that employers have preferences for employing people who are similar to themselves. This is what we call favouritism or nepotism (employing relatives) and is one form of discrimination. Carlsson and Rooth (2007) use correspondence testing to investigate the degree of discrimination in the recruitment process on the Swedish labour market. They find that male applicants with Middle Eastern sounding names are less likely to be called to an interview than similar male applicants with Swedish sounding names. Some of the employers to whom applications were sent were also interviewed and it is found that firms where a man is responsible for the recruitment are less likely to invite immigrant applicant to interviews. A surprising result is that firms located in municipalities with an immigrant share less than the average in Sweden are more likely to invite immigrant applicants than firms located in municipalities with an above average share of immigrants.

A third explanation is that immigrants have a comparative advantage in working in firms that supply ethnic goods and services. These workplaces are mostly found in retailing and restaurants. Åslund and Nordström Skans (2005) label this as sorting by skills. For the self- 
employed person who wants to recruit new workers this could also be a factor. If you own a firm that is specialized in selling ethnic goods, then you might believe that the productivity is higher for a potential employee from the same country or region than for a potential employee born in Sweden.

\subsection{The recruitment of minorities}

In many cases immigrants form ethnic minorities. However, not all immigrants form ethnic minorities, nor are all ethnic minorities immigrants. There are important differences in some respects between the situation of immigrants and that of ethnic minorities. It is self-evident that those coming from neighbouring countries like Denmark and Norway and other Western countries do not form ethnic minorities in Sweden. In a sense they are invisible immigrants and their integration or assimilation process is also not the same as for other immigrants. These "invisible" immigrants are often integrated in the labour market after a number of years. Ethnic minorities on the other hand are in many cases not economically assimilated in the same way. But there are also important similarities between the situation of nonimmigrant ethnic minorities and that of immigrants. This means that we can learn from the studies of recruitment and employment of different non-immigrant ethnic groups when analyzing the situation of immigrants.

Most US studies have been on the situation of the black minority. One result from these studies is that black job applicants are hired to a higher extent by establishments with black hiring agents than of those with white hiring agents. Two factors contribute to the explanation of that difference. Black hiring agents receive more applications from blacks and they hire a greater proportion of the blacks who apply. See Stoll, Raphael and Holzer (2004) and also Holzer and Reaser (2000). It underlines that it is important to know who is hiring, and in the 
case of self-employed people with a few employees, also the characteristics of the selfemployed.

Another part of the literature looks at the organizational practices at hiring. The results indicate that those practices are more important when the race of the applicant and the hiring agent does not match. See Kmec (2006). Informal processes make it more difficult to get a job if the race of the applicant and the hiring agent does not match. The organizational practices differ between large and small companies which may indicate that minority applicants may have more problems in getting a job in smaller companies than in larger ones when the hiring agent belongs to the majority. Some studies also show this to be the case - that minority employees have difficulties in getting jobs in non minority-owned small businesses. See Bates (1994) and Holzer 1998). These results are relevant for our study of the importance of the country of birth of the self-employed for the composition according to country of birth of his/her employees.

A number of studies of co-ethnic employees have been carried out in the Netherlands. See den Butter et al. (2004). They report results from four studies which together cover 120 ethnic owned minority firms. The owners of the firms are from India, Morocco, Pakistan and Turkey. In 50 to 84 per cent of the firms only co-ethnic personnel are employed. Ethnic segregation on the firm level is also found in the construction industry in the Netherlands. Most firms have none or only a few immigrants. The immigrants are instead concentrated in a few firms. These firms may be owned by immigrants but the data do not contain information on the owners' background.

Jacobs and Cornwell (2007) discuss how the character of the job may influence the recruitment pattern and by that the importance of networks and of discrimination. In some positions it is especially important to avoid negative performance ("goal destructive performance”). A negative performance may endanger the firm's profits and prospects. 
Knowledge of the person is very important and close networks are often preferred for recruitment. In other positions the result is not very sensitive to individual characteristics (“largely irrelevant positions”). Many people are about equally productive at the job. To follow discriminatory preferences are inexpensive in such cases. In a third type of positions (“goal enhancing positions”) an excellent employee can make a big difference. In such cases it is very important to get an excellent candidate and discriminatory hiring and the use of close networks are avoided. An implication of this classification theory is that co-ethnic employment will vary according to industry and occupation.

\section{Data and descriptive statistics}

\subsection{Data}

The population we study consists of self-employed individuals and their employees. We use cross-sectional data for 1998 and have individual data for both the self-employed and their employees. We also have some information about the firms. Each workplace has a unique identification number that is assigned both to the self-employed which we view as the employer, and the employees. This sample has been derived from a larger dataset consisting of the entire Swedish population of working age which consists of register data administrated by Statistics Sweden.

In the employment register at Statistics Sweden, which is an annual register, an individual is defined as employed at a certain workplace if he or she has received an income corresponding to at least one hour of work per week in November. This definition has limitations. First, we cannot identify employees who have been employed during other parts of the year but not in November. Second, we do not know if the self-employed have workers 
employed who they do not pay income tax for (for example foreign workers without a work permit).

We have detailed information on birth region, both for the self-employed and their employees, which allows us to divide the sample into 15 groups according to region or country of origin. In part of the analysis we present the results for three groups only, natives, Western immigrants and non-Western immigrants, to avoid too long tables. Table A1 shows the definitions used regarding birth region.

Our sample consists of in total 82,554 self-employed and 214,387 employees. Some workplaces are run by more than one self-employed. Around 45 per cent of the self-employed have a business of their own, i.e. it is not shared with another self-employed person. 39 per cent of the self-employed run a firm together with another self-employed person, and 16 per cent of the self-employed run their business together with two or more people.

Most self-employed have no employees. The share of self-employed who has employees varies with national background. The share with no employees is larger among non-Western immigrants than among natives. In this study we have only included self-employed who have between one and 35 employees. Only a few of the self-employed have more than 35 employees. See Table A2.

To define the different groups of immigrants we use information on both the birth region of the individual and the birth region of the parents. All individuals who were born in another country than Sweden are defined as immigrants from this region. Individuals who were born in Sweden but whose parents, one or both, were born in another country than Sweden are not defined as native Swedes. Instead, we use the birth region of the mother to categorize these individuals. If information on the birth region of the mother is missing, the birth region of the father is used. Individuals who are born in Sweden but for whom information is missing on 
the birth region for both parents are dropped. This group consist of 4464 individuals; 2804 are self-employed and 1660 are employees.

In this paper we want to investigate if the self-employed tend to employ people with the same national background as themselves. If an individual was born in Sweden but whose mother (or parents) are immigrants, they will share the national background with their parents. If these individuals are defined as native Swedes and are employed by their self-employed family members, we will underestimate the extent to which the self-employed employ people who share their national background. Instead, it will appear as that they employ native coworkers to a much higher extent. The reason for categorizing second-generation immigrants according to the birth region of the mother is that earlier studies have shown that the birth region of the mother has a larger impact on labour market outcomes for second-generation immigrants than the birth region of the father has. Rooth (2001), finds for example that if the mother was born in Sweden, compared to if both parents are immigrants, the probability of being unemployed is 11 percentage points lower and if the father was born in Sweden, the probability is 8 percentage points lower.

\subsection{Dependent variables}

In the regressions we use four dependent variables, all aiming at measuring the degree of segregation at the workplaces run by the self-employed. They are all binary variables. We estimate the probability that: (1) all employed in a firm originate from the same country or region as the self-employed, (2) at least one of the employees is a Western immigrant (this is only estimated for natives), (3) at least one of the employees is a non-Western immigrant (this is only estimated for natives), and (4) at least one of the employees is native (this is estimated for Western and non-Western immigrants). 
These regressions focus on the impact of different individual and firm characteristics. As it is likely that the regressors affect natives and immigrants in different ways, we estimate separate regressions for natives, Western immigrants, and non-Western immigrants.

The first outcome is a measure of the degree of segregation among the self-employed. The second and third outcomes are only analyzed for natives. These regressions will tell us who among self-employed natives will most likely employ immigrant workers.

The fourth outcome, the probability that at least one of the employees is a native, is interesting for two reasons. First, it can be an indication of which self-employed immigrants are more likely to recruit people from outside their network, assuming that the network primarily consists of people sharing similar characteristics. Second, it can be seen as a measure of how integrated the self-employed are on the labour and product markets. This interpretation has some problems, however. It is often believed that small firms run by the self-employed to a high extent hire family members and relatives. In our data we are not able to identify family member, hence we do not know if the employees are close family or relatives. If the self-employed is an immigrant and married to someone who was born in Sweden and the spouse is employed in the firm, this does not have to mean that the selfemployed has recruited employees outside his or her network. It is therefore important to take into account the composition of the self-employed if more than one person owns the business.

In Table A3 the percentages of the sample with a positive outcome on the dependent variables are presented. In the first column, we see the share that only employ co-ethnics. Self-employed who were born in Sweden and whose parents were also born in Sweden (native Swedes) are those who are most likely to only employ workers from their own group. If a regression is run with controls for individual and firm characteristics (birth region, age, gender, education, marital status, place of residence, number of self-employed, number of employees, industry, and start-up year of the firm) the result is the same. That natives are 
those who are most likely to only employ people from the same country is not a surprise since natives constitute the majority of the population. The share who are natives of those employed by native self-employed is however much higher than could be expected from the native share of the whole population and of all employees. Non-Western immigrants who are self-employed employ workers from the country and the region from which they themselves originate to a high extent. It is notable that as much as 41 per cent of the self-employed from Turkey only employ workers who were also born in Turkey.

Among Western immigrants, on average 83 per cent employ at least one native worker. Among non-Western immigrants, the share that employs natives is smaller on average, especially among immigrants from Iraq. Almost 48 per cent of the self-employed from Eastern Europe and the former Soviet Union employ at least one native worker. Around 17 per cent of the workplaces run by one native self-employed employ at least one Western immigrant and only 8 per cent employ at least one non-Western immigrant. However, looking at the workplaces run by two self-employed natives and workplaces run by more than two self-employed natives, we find that the share who employs at least one non-Western immigrant is higher, 10 and 15 per cent respectively.

The common perception about self-employed immigrants is that they mainly have restaurants and they only employ co-nationals. In table A4 we present the share who only employ co-nationals divided by four selected industries: manufacturing, construction, retailing and hotels and restaurants. Among non-Western immigrants, 42 per cent of the self-employed in hotels and restaurants only employ co-nationals but the share is even higher among native Swedes, 57 per cent. In construction the share among natives who only employ co-ethnics is higher, 75 per cent, compared to that only 11 per cent of self-employed non-Western immigrants in this industry only employ co-nationals. It is evident that the extent to which the self-employed only employ co-nationals varies between industries. However, a non-negligible 
share of non-Western restaurant owners, 58 per cent, employs at least one worker who is not a co-national.

\subsection{Sample means}

Table A5 presents sample means for native, Western, and non-Western self-employed. NonWestern immigrants are on average around five years younger than natives and more often have a higher education. A substantially higher share lives in the three metropolitan areas in Sweden (Stockholm, Göteborg, and Malmö). The largest overrepresentation is found in Stockholm. Regarding industry, non-Western immigrants to a high extent are self-employed in "hotels and restaurants". Many natives and Western immigrants are self-employed in "retailing”. Among Western immigrants, 68 per cent are from the Nordic countries. Among non-Western immigrants, the largest groups are from the new EU-countries (25 per cent), Eastern Europe and the former Soviet Union (19 per cent) and Turkey (16 per cent).

\subsection{Segregation among the self-employed}

Table 1 presents the share of employees originating from different regions and countries by national background of the self-employed. In the first and second column in the first part of Table 1 we present the immigrant share of the whole Swedish population between 16 and 64 years of age, independent of labour market status, and the immigrant share of all employees, self-employed excluded. By comparing these columns to the other columns, we get an idea whether some groups of self-employed tend to over or under employ some group. For native self-employed (column 3) 89 per cent of the employees are also native Swedes. In the whole Swedish population, this share is 81 per cent and among all employees, 85 per cent are

natives. Hence, self-employed natives tend to employ natives to a higher extent than what represents their share of the population or of all employees. This pattern is in no way unique 
for self-employed natives: all groups of self-employed tend to employ people from their own group to a higher extent than what corresponds to their share of the population or of all employees. The overall conclusion from this table is that we very clearly can see that selfemployed immigrants tend to employ people originating from the same country or region. This is primarily the case for non-Western immigrants. Self-employed non-Western immigrants do not employ natives to a high extent. The lowest share of natives among the employees is found for self-employed born in Iraq. This group, however, consists of only 70 self-employed. Also among the self-employed born in Turkey the native share of the employees is low.

All groups of self-employed, independent of region of origin, employ people from their own groups to a higher extent than could be explained by the size of the groups. We proposed four possible explanations which can both be of importance for the choice of natives to employ native workers and for immigrants to employ other immigrants. First, if the selfemployed mainly recruit workers in their family and among friends and neighbours and the network mainly consists of people similar to oneself, this can be an explanation. A second possible explanation is that natives and immigrants have preferences for employing people similar to them in terms of origin (favouritism). The third explanation, which mainly applies to the immigrant businesses, is that few native workers want to work in firms run by immigrants. Even if the immigrant entrepreneur would have wanted to hire natives, he cannot find natives who will accept his job offer. A fourth explanation is that the immigrants are more productive in producing ethnic goods and services (and that natives are more productive in producing goods and services typical for Sweden).

[TABLE 1 ABOUT HERE] 


\section{Results}

In Table 2 we present the results on the probability of only employing workers from the same region or country. We say that the self-employed who only employ co-nationals run a totally segregated firm. Although the regressions are estimated separately for three groups; natives, Western immigrants and non-Western immigrants, the dependent variable is constructed on a finer level. For all 15 defined national groups, the dependent variable is one if all people working at the workplace originate from the same region or country. For immigrants from Turkey, the dependent variable takes the value one if all people at the workplace are from Turkey but zero if for example one of the employees was born in Iran, another non-Western country etc. In the regressions for Western and non-Western immigrants we control for region of origin on the finer level.

In the regression we pay particular attention to variables that can help us to say something about the reasons for only employing co-nationals. Variables we are especially interested in are the share of immigrants in the municipality, place of residence, number of years in Sweden for immigrants and industry. The relation between the share of immigrants in the municipality and the probability of running a totally segregated firm can reveal the importance of living close to other immigrants from the same region. Number of years in Sweden can be used as a proxy for the degree of integration or assimilation. The more years immigrants have lived in Sweden, the more likely they will have natives in their networks. If we find that the probability of only employing workers from the same region decreases with time spent in Sweden, this gives us an indication of the importance of networks. Another explanation may be, however, that preferences change over time.

Self-employed in industries that require highly qualified workers, health care is probably the best example, cannot recruit workers from their network as easily as self-employed in 
low-skill industries. If networks are an important explanation, we would expect that industries requiring more qualified labour more often employ people from outside their own group.

Looking at the results, we find that most variables have the expected sign. Self-employed natives who live in municipalities with a high share of immigrants, both Western and nonWestern, are significantly less likely to run a totally segregated firm compared to selfemployed natives living in municipalities with a low share of immigrants. The reverse holds for both groups of immigrants; the higher the share of immigrants in the municipality, the more likely the self-employed are to only employ workers from the same region as themselves. The marginal effect is strongest for non-Western immigrants living in a municipality where the share of non-Western immigrants is higher than 12 per cent. Their probability of running a segregated firm is 15 percentage points higher than for non-Western immigrants living in municipalities where less than 5 per cent of the population between 16 and 64 years of age are non-Western immigrants. This marginal effect should not be given a causal interpretation. It is possible that self-employed immigrants who have a preference for employing workers from the same region or country are those who choose to live in municipalities with a high share of co-nationals.

Dummy variables for living in a metropolitan area are also included. This is likely to be correlated with the share of immigrants in the municipality since in Sweden the municipalities with the highest share of immigrants are located in the metropolitan areas. But there is also variation between the municipalities in for example Stockholm so there will not be perfect collinearity between them. It is interesting to note that it is self-employed natives who live outside the metropolitan areas who are most likely to only employ native workers, but for immigrants, it is the self-employed in Stockholm area that are most likely to only employ conationals. One explanation may be that it is easier to find employees from the same country as one's own in the Stockholm area. 
The length of stay in Sweden is negatively correlated with the probability of only employing co-nationals. We have investigated if the relationship is linear or if a second degree polynomial is needed to fit the model. It turns out that there is a linear negative relationship; the more years self-employed immigrants have spent in Sweden, the less likely they are to only employ people from the same region or country as themselves.

We include controls for birth region/country for immigrants. In the regression for nonWestern immigrants “Asia” is used as the reference group and we see that all other immigrant groups are less likely than the reference group to only employ co-nationals.

Native self-employed in "hotels and restaurants” and in “education” are less likely than self-employed within manufacturing, the reference group, to only employ natives. Selfemployed non-Western immigrants within "health care” and "other public services" which includes for example hairdressers, are significantly less likely to only employ co-nationals, compared to self-employed within manufacturing.

Some variables affect natives and immigrants in the same way. The probability decreases with number of employees which seems reasonable since the more people you want to employ, the higher is the probability that you cannot find a worker within your own family or your own network. The probability also decreases with the number of self-employed. Start-up year has no effect for immigrants, probably because it is correlated with number of years in Sweden. For natives, the results suggest that it is the oldest firms, firms started in 1985 or earlier, that are most likely to be totally segregated. Age does not seem to be of great importance and self-employed with low education are more likely to only employ people with the same national background as themselves than those with higher education.

\section{[TABLE 2 ABOUT HERE]}

Another way of analyzing the employees of the self-employed is to estimate the probability of employing at least one worker with a different national background than 
oneself. For natives we estimate the probability of employing at least one Western immigrant and the probability of employing at least one non-Western immigrant. For immigrants we estimate the probability of employing at least one native worker. The analysis of the factors affecting these probabilities can tell us who among the different groups of self-employed are most open to employing people with a different national background. Also here we will pay particular attention to the immigrants' share of the population between 16 and 64 years of age in the municipality, place of residence, number of years in Sweden for immigrants and industry.

In Table 3 we find that self-employed natives who live in municipalities with a high share of immigrants and those who live in metropolitan areas are most likely to employ both at least one Western and at least one non-Western immigrant. This result is not very surprising. Most immigrants live in these parts of Sweden and the probability for a selfemployed native to encounter an immigrant worker when recruiting new personnel is therefore highest there.

The probability of employing at least one Western immigrant is highest for selfemployed natives within the manufacturing industry (the reference group). During the 1960s and 1970s many immigrants came to Sweden from Finland. The majority was employed in the manufacturing industry and it is possible that this is part of the explanation.

The probability of employing at least one non-Western immigrant is highest in "hotels and restaurants”. It is 3 percentage points higher than in manufacturing. The probability of hiring non-Western immigrants is lowest in construction. The reason is most likely that the entrance to the building trades is highly regulated.

\section{[TABLE 3 ABOUT HERE]}

In Table 4, the results on the factors affecting self-employed immigrants of employing at least one native worker are presented. The results are inversely related to the results presented 
in Table 2. Therefore we only present the results for some selected covariates. Factors that have a positive impact on the probability of only employing co-ethnics have a negative impact on the probability of employing at least one native worker. The share of immigrants in the municipality has a large negative impact on the probability of employing natives and the probability is lower if the self-employed lives in a metropolitan area compared to living in other parts of Sweden. Number of years in Sweden has a positive impact on the outcome; the probability of employing at least one native increases with 1.3 percentage points for every year that one has lived in Sweden for non-Western immigrants and with 0.3 percentage units for Western immigrants. The results regarding industry are very strong and we find that the probability for self-employed non-Western immigrants to hire natives is 19 percentage points higher in health care than in manufacturing. Since we include country dummies for nonWestern immigrants we can see which group is most likely to employ natives. The reference group is as before immigrants from Asia. Immigrants from the new EU countries (Cyprus, Czech Republic, Estonia, Hungary, Latvia, Lithuania, Malta, Poland, Slovakia and Slovenia) are those who are most likely to employ at least one native. ${ }^{1}$ Self-employed from Asia and from Iraq have a low probability of hiring natives.

[TABLE 4 ABOUT HERE]

\section{Concluding Remarks}

In this paper we have shown that the firms of the self-employed are highly segregated workplaces where a majority of the employees originate from the same region or country as the self-employed does. Since we assume that the self-employed person is the one who in fact recruits people to the firm, this can be interpreted as that these employers hire workers similar to themselves.

\footnotetext{
${ }^{1}$ The marginal effect for self-employed from Africa is larger in size but this group is so small that we should interpret the results with care.
} 
We discussed four different explanations for this pattern. The first one is that the selfemployed recruit people from their network and the network mainly consists of people similar to them. The idea that networks play a large role is related to that the share of people in the neighbourhood who originate from the same region or country affects the composition of the network. The second explanation is that the self-employed have preferences against employing people different from themselves. The third explanation is that the supply of native workers for self-employed immigrants is lower than the supply for natives, and vice versa for immigrant workers. The fourth explanation is that immigrants have a comparative advantage in the production of ethnic goods and services.

We cannot discriminate between these hypotheses. Our results on the impact of the share of immigrants in the municipality shows that self-employed natives who live in immigrant dense municipalities are more likely to employ immigrants compared to colleagues living in municipalities with low shares of immigrants. This result could be interpreted in favour of the network hypothesis. However, the type of municipality a person lives in can be correlated with preferences for employing immigrants. It is possible that self-employed natives who live in municipalities with few immigrants are more negatively disposed towards employing immigrants. Hence, we cannot rule out the possibility that this result is an indication that preferences are part of the explanation. The supply of workers will also differ between municipalities with a high and a low share of immigrants respectively, so an explanation on the supply side is also possible.

The positive association between number of years in Sweden and the probability for immigrants to employ at least one native worker can also be related to the explanations. It was argued that the network of immigrants is more likely to include natives, the more years you have lived in Sweden so this is consistent with the network hypothesis. But preferences among self-employed immigrants for employing native workers can also be important, under 
the assumption that preferences change over years spent in Sweden. Newly arrived immigrants perhaps have stronger preferences against hiring native workers since they do not know the language, are not familiar with the culture and so forth. Also, the supply of native workers can vary with years spent in Sweden for immigrants if the native worker is informed of the number of years the self-employed immigrant has lived in Sweden.

As has become clear, self-employed immigrants tend to employ people from their own home countries. A question of great policy relevance following this result is to what extent an increase in the number of self-employed immigrants can increase employment among immigrants in general in Sweden? A related question is if an expansion of immigrant employment in immigrant-owned firms may lead to more segregation in the long run. ${ }^{2}$ Therefore we need to continue research on the effects of self-employment on unemployment and in particular, if self-employment among immigrants can reduce unemployment in this group.

\footnotetext{
${ }^{2}$ See den Butter et al. (2004) for a discussion of that subject.
} 


\section{Tables}

Table 1 Share of employees with different ethnical background for different groups of self-employed, per cent

\begin{tabular}{|c|c|c|c|c|c|c|c|c|c|}
\hline \multirow[b]{2}{*}{ Employees } & \multicolumn{9}{|c|}{ SELF-EMPLOYED } \\
\hline & $\begin{array}{l}\text { The whole } \\
\text { population } \\
\text { in Sweden }\end{array}$ & $\begin{array}{c}\text { All } \\
\text { employed } \\
\text { (self- } \\
\text { employed } \\
\text { excluded) }\end{array}$ & Sweden & $\begin{array}{c}\text { Nordic } \\
\text { countries }\end{array}$ & $\begin{array}{c}\text { EU- } \\
\text { countries }\end{array}$ & $\begin{array}{l}\text { New EU- } \\
\text { countries }\end{array}$ & $\begin{array}{c}\text { Eastern } \\
\text { Europe and } \\
\text { the former } \\
\text { Soviet } \\
\text { Union }\end{array}$ & $\begin{array}{c}\text { USA, Canada, } \\
\text { Japan, } \\
\text { Oceania }\end{array}$ & $\begin{array}{c}\text { South and } \\
\text { Central } \\
\text { America }\end{array}$ \\
\hline Sweden & 80.9 & 85.3 & 89.0 & 73.3 & 66.6 & 70.8 & 44.7 & 78.5 & 43.1 \\
\hline Nordic countries & 7.5 & 7.3 & 5.9 & 19.6 & 6.2 & 8.9 & 5.3 & 5.3 & 4.6 \\
\hline EU-countries (EU12) & 2.1 & 1.8 & 1.3 & 1.5 & 14.3 & 2.3 & 2.3 & 5.3 & 4.0 \\
\hline New EU-countries & 1.5 & 1.2 & 0.8 & 1.3 & 1.8 & 10.0 & 1.8 & 2.5 & 2.3 \\
\hline $\begin{array}{l}\text { Eastern Europe and the former } \\
\text { Soviet Union }\end{array}$ & 2.5 & 1.4 & 1.3 & 1.6 & 3.5 & 3.8 & 39.5 & 3.5 & 3.4 \\
\hline USA, Canada, Japan and Oceania & 0.4 & 0.3 & 0.2 & 0.2 & 0.6 & 0.5 & 0.5 & 3.5 & 1.1 \\
\hline South and Central America & 0.9 & 0.6 & 0.3 & 0.5 & 1.8 & 0.6 & 0.8 & 0.8 & 33.9 \\
\hline North Africa and the Middle East & 0.8 & 0.3 & 0.2 & 0.2 & 0.6 & 0.7 & 1.2 & 0.0 & 1.7 \\
\hline Africa & 0.7 & 0.3 & 0.1 & 0.4 & 0.4 & 0.5 & 0.2 & 0.3 & 1.1 \\
\hline Iran & 0.8 & 0.4 & 0.1 & 0.3 & 0.5 & 0.6 & 0.1 & 0.0 & 0.6 \\
\hline Iraq & 0.5 & 0.1 & 0.1 & 0.2 & 0.3 & 0.1 & 0.3 & 0.0 & 0.6 \\
\hline Turkey & 0.6 & 0.3 & 0.1 & 0.3 & 1.0 & 0.5 & 0.9 & 0.0 & 1.7 \\
\hline Asia & 1.1 & 0.7 & 0.5 & 0.6 & 2.5 & 0.6 & 2.3 & 0.3 & 1.7 \\
\hline Number of employees & - & 3574042 & 99407 & 6107 & 2867 & 1276 & 868 & 395 & 174 \\
\hline Number of self-employed & - & - & 31834 & 2022 & 860 & 439 & 399 & 123 & 76 \\
\hline
\end{tabular}


Table 1 continued

\begin{tabular}{|c|c|c|c|c|c|c|c|c|}
\hline Employees & $\begin{array}{l}\text { North Africa } \\
\text { and the } \\
\text { Middle East }\end{array}$ & Africa & Iran & Iraq & Turkey & Asia & $\begin{array}{c}\text { Two self- } \\
\text { employed. at } \\
\text { least one } \\
\text { Western } \\
\text { immigrant }\end{array}$ & $\begin{array}{l}\text { Two self- } \\
\text { employed. at } \\
\text { least one } \\
\text { non-Western } \\
\text { immigrant }\end{array}$ \\
\hline Sweden, parents born in Sweden & 30.9 & 48.5 & 27.6 & 16.8 & 26.3 & 38.5 & 78.4 & 65.4 \\
\hline Nordic countries & 6.1 & 3.1 & 3.6 & 3.4 & 3.2 & 4.8 & 12.4 & 5.8 \\
\hline EU-countries (EU12) & 2.7 & 4.1 & 1.7 & 2.5 & 3.0 & 3.5 & 3.6 & 2.9 \\
\hline New EU-countries & 1.3 & 1.0 & 1.9 & 1.7 & 1.3 & 2.8 & 0.9 & 4.0 \\
\hline $\begin{array}{l}\text { Eastern Europe and the former } \\
\text { Soviet Union }\end{array}$ & 5.5 & 3.1 & 4.3 & 0.8 & 3.6 & 4.3 & 1.9 & 7.5 \\
\hline USA, Canada, Japan, Oceania & 0.0 & 0.0 & 0.0 & 0.0 & 0.1 & 0.5 & 0.4 & 0.3 \\
\hline South and Central America & 1.2 & 1.0 & 1.1 & 0.0 & 0.8 & 1.3 & 0.5 & 1.7 \\
\hline North Africa and the Middle East & 39.5 & 8.2 & 4.9 & 10.9 & 6.7 & 1.0 & 0.3 & 2.4 \\
\hline Africa & 1.3 & 26.8 & 1.7 & 0.8 & 0.4 & 1.5 & 0.1 & 0.4 \\
\hline Iran & 1.3 & 0.0 & 42.3 & 7.6 & 1.6 & & 0.2 & 1.1 \\
\hline Iraq & 3.7 & 1.0 & 4.5 & 51.3 & 2.8 & 0.3 & 0.1 & 0.5 \\
\hline Turkey & 4.7 & 1.0 & 3.8 & 4.2 & 48.8 & 1.0 & 0.3 & 2.8 \\
\hline Asia & 1.8 & 2.1 & 2.6 & 0.0 & 1.3 & 40.6 & 0.9 & 5.2 \\
\hline Number of employees & 602 & 97 & 468 & 119 & 825 & 397 & 8945 & 2539 \\
\hline Number of self-employed & 314 & 48 & 248 & 70 & 409 & 159 & 3874 & 1374 \\
\hline
\end{tabular}


Table 1 continued

\begin{tabular}{|c|c|c|c|c|c|c|}
\hline Employees & $\begin{array}{l}\text { Two self- } \\
\text { employed, no } \\
\text { natives }\end{array}$ & $\begin{array}{l}\text { Two self- } \\
\text { employed, no } \\
\text { immigrants }\end{array}$ & $\begin{array}{l}\text { More than two } \\
\text { self-employed, } \\
\text { at least one } \\
\text { Western } \\
\text { immigrant }\end{array}$ & $\begin{array}{l}\text { More than two } \\
\text { self-employed, } \\
\text { at least one } \\
\text { non-Western } \\
\text { immigrant }\end{array}$ & $\begin{array}{l}\text { More than two } \\
\text { self-employed, } \\
\text { no natives }\end{array}$ & $\begin{array}{l}\text { More than two } \\
\text { self-employed, } \\
\text { no immigrants }\end{array}$ \\
\hline Sweden. parents Sweden & 50.6 & 89.9 & 82.3 & 76.4 & 69.3 & 90.1 \\
\hline Nordic countries & 11.3 & 5.5 & 10.5 & 7.0 & 4.9 & 5.2 \\
\hline EU-countries (EU12) & 7.7 & 1.2 & 2.0 & 2.4 & 4.2 & 1.2 \\
\hline New EU-countries & 3.1 & 0.8 & 0.8 & 2.1 & 3.1 & 0.6 \\
\hline $\begin{array}{l}\text { Eastern Europe and the former Soviet } \\
\text { Union }\end{array}$ & 4.6 & 1.2 & 2.2 & 3.2 & 3.8 & 1.4 \\
\hline USA, Canada, Japan, Oceania & 0.3 & 0.2 & 0.2 & 0.1 & 0.0 & 0.2 \\
\hline South and Central America & 3.7 & 0.3 & 0.6 & 1.0 & 0.7 & 0.3 \\
\hline North Africa and the Middle East & 2.1 & 0.1 & 0.3 & 0.8 & 2.1 & 0.2 \\
\hline Africa & 0.6 & 0.1 & 0.2 & 0.1 & 0.0 & 0.1 \\
\hline Iran & 0.6 & 0.1 & 0.2 & 0.4 & 0.0 & 0.1 \\
\hline Iraq & 0.0 & 0.1 & 0.1 & 0.2 & 0.3 & 0.1 \\
\hline Turkey & 2.1 & 0.1 & 0.1 & 2.6 & 3.8 & 0.1 \\
\hline Asia & 13.2 & 0.5 & 0.6 & 3.6 & 7.7 & 0.4 \\
\hline Number of employees & 326 & 61847 & 3807 & 899 & 287 & 22135 \\
\hline Number of self-employed & 156 & 26490 & 2024 & 521 & 188 & 10926 \\
\hline
\end{tabular}


Table 2 Probability of only employing workers from the same region. Marginal effects. Standard errors estimated with clustering on workplace are presented in parentheses.

\begin{tabular}{|c|c|c|c|}
\hline & Natives & $\begin{array}{l}\text { Western } \\
\text { immigrants }\end{array}$ & $\begin{array}{c}\text { Non-Western } \\
\text { immigrants }\end{array}$ \\
\hline \multicolumn{4}{|l|}{ Share of immigrants in the municipality } \\
\hline Low share of Western immigrants ${ }^{3}$ & Ref. & Ref. & \\
\hline \multirow[t]{2}{*}{ Intermediate share of immigrants } & -0.108 & 0.041 & \\
\hline & $(0.006)^{* * *}$ & $(0.014)^{* * *}$ & \\
\hline High share of Western immigrants & -0.223 & $\begin{array}{c}0.108 \\
(028) * * *\end{array}$ & \\
\hline Low share of non-Western immigrants ${ }^{4}$ & Ref. & & Ref. \\
\hline Intermediate share of non-Western immigrants & $\begin{array}{c}-0.043 \\
(0.006)^{* * *}\end{array}$ & & $\begin{array}{c}0.087 \\
(0.030)^{* * *}\end{array}$ \\
\hline High share of non-Western immigrants & $\begin{array}{c}-0.034 \\
(0.007)^{* * *}\end{array}$ & & $\begin{array}{c}0.152 \\
(0.033)^{* * *}\end{array}$ \\
\hline \multicolumn{4}{|l|}{ Place of residence } \\
\hline Stockholm & $\begin{array}{c}-0.123 \\
(0.009)^{* * *}\end{array}$ & $\begin{array}{c}0.031 \\
(0.011)^{* * *}\end{array}$ & $\begin{array}{c}0.046 \\
(0.027)^{*}\end{array}$ \\
\hline Göteborg & $\begin{array}{c}-0.071 \\
(0.012)^{* * *}\end{array}$ & $\begin{array}{c}0.036 \\
(0.025)\end{array}$ & $\begin{array}{c}0.020 \\
(0.042)\end{array}$ \\
\hline Malmö & $\begin{array}{c}-0.093 \\
(0.013)^{* * *}\end{array}$ & $\begin{array}{l}-0.002 \\
(0.020)\end{array}$ & $\begin{array}{c}0.053 \\
(0.045)\end{array}$ \\
\hline Number of years in Sweden & & $\begin{array}{c}-0.002 \\
(0.000)^{* * *}\end{array}$ & $\begin{array}{c}-0.009 \\
(0.001)^{* * *}\end{array}$ \\
\hline \multicolumn{4}{|l|}{ Birth Region } \\
\hline \multicolumn{2}{|l|}{ Nordic countries } & Ref. & \\
\hline EU12 & & $\begin{array}{c}-0.032 \\
(0.008)^{* * *}\end{array}$ & \\
\hline USA, Canada, Australia and Japan & & $\begin{array}{c}-0.061 \\
(0.010)^{* * *}\end{array}$ & \\
\hline Asia & & & Ref. \\
\hline New EU-countries & & & $\begin{array}{c}-0.181 \\
(0.029)^{* * *}\end{array}$ \\
\hline Eastern Europe and the former Soviet Union & & & $\begin{array}{l}-0.033 \\
(0.035)\end{array}$ \\
\hline South and Central America & & & $\begin{array}{c}-0.098 \\
(0.050)^{*}\end{array}$ \\
\hline North Africa and the Middle East & & & $\begin{array}{c}-0.095 \\
(0.032)^{* * *}\end{array}$ \\
\hline Africa & & & $\begin{array}{c}-0.171 \\
(0.033)^{* * *}\end{array}$ \\
\hline Iran & & & $\begin{array}{l}-0.070 \\
(0.037)^{*}\end{array}$ \\
\hline Iraq & & & $\begin{array}{l}-0.071 \\
(0.049)\end{array}$ \\
\hline Turkey & & & $\begin{array}{l}-0.057 \\
(0.035)\end{array}$ \\
\hline
\end{tabular}

\footnotetext{
${ }^{3}$ Low share: 3 per cent or less of the population in the municipality between 16 and 64 years of age are Western immigrants. Intermediate share: Between 3 and 8 per cent of the population are Western immigrants. High share: More than 8 per cent of the population are Western immigrants.

${ }^{4}$ Low share: 5 per cent or less of the population in the municipality between 16 and 64 years of age are nonWestern immigrants. Intermediate share: Between 5 and 12 per cent of the population are non-Western immigrants. High share: More than 12 per cent of the population are non-Western immigrants
} 


\begin{tabular}{|c|c|c|c|}
\hline \multicolumn{4}{|l|}{ Industry } \\
\hline \multirow[t]{2}{*}{ Agriculture and fishing } & 0.114 & 0.006 & -0.062 \\
\hline & $(0.009)^{* * *}$ & $(0.023)$ & $(0.099)$ \\
\hline \multirow[t]{2}{*}{ Construction } & 0.114 & 0.015 & -0.070 \\
\hline & $(0.008)^{* * *}$ & $(0.017)$ & $(0.070)$ \\
\hline \multirow[t]{2}{*}{ Retailing } & 0.064 & -0.022 & -0.009 \\
\hline & $(0.007)^{* * *}$ & $(0.012)^{*}$ & $(0.046)$ \\
\hline \multirow[t]{2}{*}{ Hotels and restaurants } & -0.069 & 0.006 & 0.079 \\
\hline & $(0.015)^{* * *}$ & $(0.018)$ & $(0.046)^{*}$ \\
\hline \multirow[t]{2}{*}{ Transport } & 0.097 & -0.016 & -0.038 \\
\hline & $(0.008)^{* * *}$ & $(0.014)$ & $(0.046)$ \\
\hline \multirow[t]{2}{*}{ Financial services } & 0.070 & 0.112 & \\
\hline & $(0.040)^{*}$ & $(0.185)$ & \\
\hline \multirow[t]{2}{*}{ Industrial services } & 0.045 & 0.022 & 0.040 \\
\hline & $(0.009)^{* * *}$ & $(0.017)$ & $(0.058)$ \\
\hline \multirow[t]{2}{*}{ Education } & -0.024 & -0.012 & -0.131 \\
\hline & $(0.027)$ & $(0.049)$ & $(0.142)$ \\
\hline \multirow[t]{2}{*}{ Health care } & 0.017 & -0.007 & -0.135 \\
\hline & $(0.016)$ & $(0.024)$ & $(0.047)^{* * *}$ \\
\hline \multirow[t]{2}{*}{ Other social services } & 0.043 & -0.016 & -0.167 \\
\hline & $(0.013)^{* * *}$ & $(0.017)$ & $(0.034)^{* * *}$ \\
\hline \multirow[t]{2}{*}{ Unknown } & 0.085 & -0.013 & -0.088 \\
\hline & $(0.031)^{* * *}$ & $(0.041)$ & $(0.068)$ \\
\hline \multirow[t]{2}{*}{ Number of employees } & -0.039 & -0.025 & -0.095 \\
\hline & $(0.001)^{* * *}$ & $(0.002)^{* * *}$ & $(0.010)^{* * *}$ \\
\hline \multicolumn{4}{|c|}{ Number of self-employed (employers) } \\
\hline One employer & Ref. & Ref. & Ref. \\
\hline \multirow[t]{2}{*}{ Two employers } & -0.069 & -0.022 & -0.086 \\
\hline & $(0.005)^{* * *}$ & $(0.009)^{* *}$ & $(0.023)^{* * *}$ \\
\hline \multirow[t]{2}{*}{ More than two employers } & -0.114 & -0.063 & -0.078 \\
\hline & $(0.010)^{* * *}$ & $(0.011)^{* * *}$ & $(0.057)$ \\
\hline \multicolumn{4}{|l|}{ Start year of the firm } \\
\hline \multicolumn{4}{|l|}{1985 or earlier } \\
\hline \multirow[t]{2}{*}{ 1986-1989 } & -0.040 & -0.005 & 0.031 \\
\hline & $(0.007)^{* * *}$ & $(0.011)$ & $(0.039)$ \\
\hline \multirow[t]{2}{*}{ 1990-1994 } & -0.047 & 0.029 & 0.039 \\
\hline & $(0.007)^{* * *}$ & $(0.013)^{* *}$ & $(0.037)$ \\
\hline \multirow[t]{2}{*}{ 1995-1998 } & -0.030 & 0.023 & 0.026 \\
\hline & $(0.009) * * *$ & $(0.015)$ & $(0.038)$ \\
\hline \multicolumn{4}{|l|}{ Age } \\
\hline $20-30$ & Ref. & Ref. & Ref. \\
\hline $31-40$ & -0.021 & 0.015 & -0.052 \\
\hline & $(0.010)^{* *}$ & $(0.025)$ & $(0.028) *$ \\
\hline $41-50$ & -0.014 & 0.033 & -0.013 \\
\hline & $(0.010)$ & $(0.027)$ & $(0.033)$ \\
\hline $51-60$ & 0.002 & 0.028 & 0.024 \\
\hline & $(0.010)$ & $(0.026)$ & $(0.043)$ \\
\hline $60-64$ & 0.012 & 0.033 & 0.103 \\
\hline & $(0.013)$ & $(0.038)$ & $(0.092)$ \\
\hline
\end{tabular}




\begin{tabular}{lccc}
\hline Education & & & \\
Low education & Ref. & Ref. & Ref. \\
Intermediate education & -0.027 & -0.018 & -0.013 \\
& $(0.004)^{* * *}$ & $(0.008)^{* *}$ & $(0.020)$ \\
High education & -0.042 & -0.052 & -0.055 \\
& $(0.007)^{* * *}$ & $(0.010)^{* * *}$ & $(0.026)^{* *}$ \\
Missing information & -0.013 & -0.037 & 0.034 \\
& $(0.039)$ & $(0.014)^{* * *}$ & $(0.049)$ \\
Female & 0.014 & 0.013 & -0.013 \\
& $(0.004)^{* * *}$ & $(0.008)^{*}$ & $(0.018)$ \\
Married & 0.010 & 0.008 & 0.010 \\
& $(0.005)^{* *}$ & $(0.008)$ & $(0.020)$ \\
\hline Observations $_{\text {Correctly classified }}^{\mathrm{a}}$ & 72820 & 3375 & 2959 \\
\hline
\end{tabular}

Notes: Robust standard errors in parentheses. * significant at 10\%; ** significant at 5\%; *** significant at $1 \%$

${ }^{a}$ An observation is classified as positive if the predicted probability is larger than or equal to 0.5 . An observation is classified as negative if the predicted probability is less than 0.5 . The percentage correctly classified shows the share of the sample that has been classified in the correct group. 
Table 3 Probability for natives of employing at least one immigrant. Marginal effects. Standard errors estimated with clustering on workplace are presented in parentheses.

\begin{tabular}{|c|c|c|}
\hline & $\begin{array}{l}\text { Probability of } \\
\text { employing at least one } \\
\text { Western immigrant }\end{array}$ & $\begin{array}{c}\text { Probability of employing at } \\
\text { least one non-Western } \\
\text { immigrant }\end{array}$ \\
\hline \multicolumn{3}{|l|}{ Share of immigrants in the municipality } \\
\hline Low share of Western immigrants ${ }^{5}$ & ref. & \\
\hline \multirow[t]{2}{*}{ Intermediate share of immigrants } & 0.089 & \\
\hline & $(0.005)^{* * *}$ & \\
\hline High share of Western immigrants & $\begin{array}{c}0.215 \\
(0.011)^{* * *}\end{array}$ & \\
\hline \multirow{3}{*}{$\begin{array}{l}\text { Low share of non-Western immigrants }{ }^{6} \\
\text { Intermediate share of non-Western } \\
\text { immigrants }\end{array}$} & & Ref. \\
\hline & & 0.045 \\
\hline & & $(0.004)^{* * *}$ \\
\hline \multirow[t]{2}{*}{ High share of non-Western immigrants } & & 0.036 \\
\hline & & $(0.004)^{* * *}$ \\
\hline \multicolumn{3}{|l|}{ Place of residence } \\
\hline \multirow[t]{2}{*}{ Stockholm } & 0.086 & 0.069 \\
\hline & $(0.007) * * *$ & $(0.006)^{* * *}$ \\
\hline \multirow[t]{2}{*}{ Göteborg } & 0.034 & 0.053 \\
\hline & $(0.010) * * *$ & $(0.009) * * *$ \\
\hline \multirow[t]{2}{*}{ Malmö } & 0.031 & 0.094 \\
\hline & $(0.011)^{* * *}$ & $(0.010)^{* * *}$ \\
\hline \multicolumn{3}{|l|}{ Industry } \\
\hline Manufacturing & Ref. & Ref. \\
\hline \multirow[t]{2}{*}{ Agriculture and fishing } & -0.071 & -0.052 \\
\hline & $(0.007)^{* * *}$ & $(0.003) * * *$ \\
\hline \multirow[t]{2}{*}{ Construction } & -0.043 & -0.067 \\
\hline & $(0.007)^{* * *}$ & $(0.002)^{* * *}$ \\
\hline \multirow{2}{*}{ Retailing } & -0.031 & -0.040 \\
\hline & $(0.006)^{* * *}$ & $(0.003) * * *$ \\
\hline \multirow[t]{2}{*}{ Hotels and restaurants } & 0.025 & 0.030 \\
\hline & $(0.013)^{* *}$ & $(0.008)^{* * *}$ \\
\hline \multirow[t]{2}{*}{ Transport } & -0.031 & -0.060 \\
\hline & $(0.008)^{* * *}$ & $(0.003) * * *$ \\
\hline \multirow[t]{2}{*}{ Financial services } & -0.005 & -0.048 \\
\hline & $(0.040)$ & $(0.010)^{* * *}$ \\
\hline \multirow[t]{2}{*}{ Industrial services } & -0.025 & -0.032 \\
\hline & $(0.008)^{* * *}$ & $(0.003) * * *$ \\
\hline \multirow[t]{2}{*}{ Education } & 0.020 & 0.016 \\
\hline & $(0.023)$ & $(0.018)$ \\
\hline \multirow[t]{2}{*}{ Health care } & -0.010 & -0.034 \\
\hline & $(0.014)$ & $(0.006)^{* * *}$ \\
\hline \multirow{2}{*}{ Other social services } & -0.035 & -0.023 \\
\hline & $(0.012)^{* * *}$ & $(0.006)^{* * *}$ \\
\hline Unknown & -0.069 & -0.029 \\
\hline Observations & 72820 & 72820 \\
\hline Correctly classified & $82.1 \%$ & $90.2 \%$ \\
\hline
\end{tabular}

Notes: The regressions also include controls for: number of employees, number of self-employed, start-up year of the firm, age, education, gender, and marital status. Robust standard errors in parentheses. * significant at $10 \%$; ** significant at $5 \%$; *** significant at $1 \%$

\footnotetext{
${ }^{5}$ See table 2 for an explanation

${ }^{6}$ See table 2 for an explanation
} 
Table 4 Probability of employing at least one native. Marginal effects. Standard errors estimated with clustering on workplace are presented in parentheses.

\begin{tabular}{|c|c|c|}
\hline & Western immigrants & $\begin{array}{l}\text { Non-Western } \\
\text { immigrants }\end{array}$ \\
\hline \multicolumn{3}{|l|}{ Share of immigrants in the municipality } \\
\hline \multicolumn{3}{|l|}{ Low share of Western immigrants ${ }^{7}$} \\
\hline \multirow[t]{2}{*}{ Intermediate share of immigrants } & -0.076 & -0.020 \\
\hline & $(0.020)^{* * *}$ & $(0.038)$ \\
\hline \multirow[t]{2}{*}{ High share of Western immigrants } & -0.175 & -0.060 \\
\hline & $(0.034) * * *$ & $(0.045)$ \\
\hline \multicolumn{3}{|l|}{ Low share of non-Western immigrants ${ }^{8}$} \\
\hline \multirow{2}{*}{$\begin{array}{l}\text { Intermediate share of non-Western } \\
\text { immigrants }\end{array}$} & -0.040 & -0.183 \\
\hline & $(0.017)^{* *}$ & $(0.034)^{* * *}$ \\
\hline \multirow[t]{2}{*}{ High share of non-Western immigrants } & -0.053 & -0.242 \\
\hline & $(0.020)^{* * *}$ & $(0.038)^{* * *}$ \\
\hline \multicolumn{3}{|l|}{ Place of residence } \\
\hline \multirow[t]{2}{*}{ Stockholm } & -0.062 & -0.127 \\
\hline & $(0.019)^{* * *}$ & $(0.036)^{* * *}$ \\
\hline \multirow[t]{2}{*}{ Göteborg } & -0.008 & -0.088 \\
\hline & $(0.031)$ & $(0.049)^{*}$ \\
\hline \multirow[t]{2}{*}{ Malmö } & -0.066 & -0.033 \\
\hline & $(0.040)^{*}$ & $(0.051)$ \\
\hline \multirow[t]{2}{*}{ Number of years in Sweden } & 0.003 & 0.013 \\
\hline & $(0.001)^{* * *}$ & $(0.002)^{* * *}$ \\
\hline \multicolumn{3}{|l|}{ Birth Region } \\
\hline \multicolumn{3}{|l|}{ The Nordic countries } \\
\hline \multirow[t]{2}{*}{ EU12 } & 0.015 & \\
\hline & $(0.014)$ & \\
\hline \multirow{2}{*}{$\begin{array}{l}\text { The US, Canada, Australia } \\
\text { and Japan }\end{array}$} & 0.059 & \\
\hline & $(0.027)^{* *}$ & \\
\hline \multicolumn{3}{|l|}{ Asia } \\
\hline \multirow[t]{2}{*}{ New EU-countries } & & 0.227 \\
\hline & & $(0.045)^{* * *}$ \\
\hline \multirow[t]{2}{*}{ Eastern Europe and the former Soviet Union } & & 0.091 \\
\hline & & $(0.045)^{* *}$ \\
\hline \multirow[t]{2}{*}{ South and Central America } & & 0.051 \\
\hline & & $(0.072)$ \\
\hline \multirow{2}{*}{ North Africa and the Middle East } & & 0.071 \\
\hline & & $(0.049)$ \\
\hline \multirow[t]{2}{*}{ Africa } & & 0.310 \\
\hline & & $(0.056)^{* * *}$ \\
\hline \multirow[t]{2}{*}{ Iran } & & 0.022 \\
\hline & & $(0.054)$ \\
\hline \multirow[t]{2}{*}{ Iraq } & & -0.117 \\
\hline & & $(0.078)$ \\
\hline \multirow[t]{2}{*}{ Turkey } & & 0.073 \\
\hline & & $(0.048)$ \\
\hline
\end{tabular}

\footnotetext{
${ }^{7}$ See table 2 for an explanation.

${ }^{8}$ See table 2 for an explanation
} 


\begin{tabular}{lcc}
\hline Industry & & \\
Manufacturing & -0.060 & 0.053 \\
Agriculture and Fishing & $(0.046)$ & $(0.143)$ \\
& -0.003 & 0.199 \\
Construction & $(0.024)$ & $(0.088)^{* *}$ \\
& 0.044 & 0.109 \\
Retailing & $(0.018)^{* *}$ & $(0.052)^{* *}$ \\
& -0.109 & -0.114 \\
Hotels and restaurants & $(0.034)^{* * *}$ & $(0.050)^{* *}$ \\
Transport & 0.056 & 0.068 \\
& $(0.020)^{* * *}$ & $(0.058)$ \\
Financial services & -0.202 & \\
& $(0.239)$ & -0.091 \\
Industrial services & -0.072 & $(0.059)$ \\
& $(0.030)^{* *}$ & 0.372 \\
Education & -0.030 & $(0.165)^{* *}$ \\
& $(0.083)$ & 0.192 \\
Health care & 0.047 & $(0.071)^{* * *}$ \\
Other social services & $(0.032)$ & 0.210 \\
& 0.034 & $(0.061)^{* * *}$ \\
Unknown & $(0.027)$ & 0.227 \\
& 0.020 & $(0.092)^{* *}$ \\
\hline Observations & $(0.075)$ & 2959 \\
Correctly classified, \% & 3375 & $74.4 \%$ \\
\hline
\end{tabular}

Notes: The regressions also include controls for: number of employees, number of self-employed, start-up year of the firm, age, education, gender, and marital status. Robust standard errors in parentheses. * significant at $10 \%$; ** significant at $5 \%$; *** significant at $1 \%$ 


\section{References}

Åslund, O and O Nordström Skans (2005), "Will I See You at Work? Ethnic workplace segregation in Sweden 1985-2002”, IFAU Working Paper, No 2005:24.

Bates, T (1994), "Utilization of minority employees in small business: A comparison of nonminority and black-owned urban enterprises”, Review of Black Political Economy, 23(1), 113-122.

Behtoui, A (2006a), “Nätverksrekrytering, infödda och invandrare”, in På tröskeln till lönearbete, A Neergaard (ed.), SOU 2006:60.

Behtoui, A (2006b), Unequal Opportunities. The impact of social capital and recruitment methods on immigrants and their children in the Swedish labour market, $\mathrm{PhD}$ thesis, Linköping Studies in Arts and Science, No. 365, Linköping University.

Carlsson, M and D-O Rooth (2007), "Evidence of Ethnic Discrimination in the Swedish Labor Market Using Experimental Data”, Labour Economics, vol. 14, 716-729.

den Butter, F A G, E Masurel and R H J Mosch (2004), "The Economics of Co-ethnic Employment”, Tinbergen Institute Discussion Paper TI 2004-027/3.

Ekström, E (2001), “Arbetsgivarnas rekryteringsbeteende”, IFAU Forskningsrapport 2001:3.

le Grand, C and R Szulkin (2002), “Permanent Disadvantage or Gradual Integration: Explaining the Immigrant-Native Earnings Gap in Sweden”, Labour, 16, 37-64.

Holzer, H J (1998), “Why Do Small Establishments Hire Fewer Blacks than Large Ones?”, Human Resources, 33, 896-914.

Holzer, H J and J Reaser (2000), "Black Applicants, Black Employees, and Urban Labor Market Policy”, Journal of Urban Economics, 48, 365-387.

Jacobs, D and B Cornwell (2007), "Labor markets and organizations: A screening theory of hiring networks and racially homogeneous employment”, Research in Social Stratification and Mobility, 27, 39-55.

Kmec, J A (2006), “White hiring agents’ organizational practices and out-group hiring”, Social Science Research, 35, 668-701.

Olli Segendorf, Å (2005), “Job Search by Immigrants in Sweden”, in Job Search Strategies and Wage Effects for Immigrants, Swedish Institute for Social Research, Dissertation Series No. 65.

Rooth, Dan-Olof (2001), ”Etnisk diskriminering och "Sverige-specifik” kunskap - vad kan vi lära från studier av adopterade och andra generationens invandrare?”, Ekonomisk Debatt, 8, 535-546.

Stoll, M A, S Raphael and H J Holzer (2004), “Black Job Applicants and the Hiring Officer’s Race”, Industrial and Labor Relations Review, 57(2), 267-287. 


\section{Appendix}

Table A1 Definition of immigrant groups

\begin{tabular}{|c|c|c|}
\hline Birth region & Group & Included countries \\
\hline $\begin{array}{l}\text { Sweden, both parents born in } \\
\text { Sweden }\end{array}$ & Natives & Sweden \\
\hline $\begin{array}{l}\text { Sweden, one parent born in } \\
\text { Sweden }\end{array}$ & Natives & Sweden \\
\hline $\begin{array}{l}\text { Sweden, both parents are } \\
\text { immigrants }\end{array}$ & Natives & Sweden \\
\hline Nordic countries & West & Denmark, Finland, Iceland, Norway \\
\hline EU-countries and Switzerland & West & $\begin{array}{l}\text { Belgium, France, Greece, Ireland, Italy, Luxembourg, } \\
\text { the Netherlands, Portugal, Spain, Great Britain and } \\
\text { Northern Ireland, Germany, Austria, Switzerland }\end{array}$ \\
\hline USA, Canada, Japan, Oceania & West & USA, Canada, Japan, Oceania \\
\hline New EU-countries & Non-West & $\begin{array}{l}\text { Poland, Estonia, Latvia, Lithuania, Hungary, Czech } \\
\text { Republic, Slovakia, Slovenia, Malta and Cyprus }\end{array}$ \\
\hline $\begin{array}{l}\text { Eastern Europe and the former } \\
\text { Soviet Union }\end{array}$ & Non-West & $\begin{array}{l}\text { Yugoslavia, former Yugoslavia, Albania, Bulgaria, } \\
\text { Rumania, Moldavia, Russia, Ukraine, Belarus, and } \\
\text { other countries in the former Soviet Union. }\end{array}$ \\
\hline South and Central America & Non-West & South and Central America \\
\hline North Africa and the Middle East & Non-West & $\begin{array}{l}\text { Egypt, Libya, Tunisia, Algeria, Morocco, Israel, } \\
\text { Palestine, Syria, Lebanon, Jordan, South Yemen, } \\
\text { Yemen, the United Arab Emirate, Kuwait, Bahrain, } \\
\text { Qatar, Saudi Arabia. }\end{array}$ \\
\hline Africa & Non-West & $\begin{array}{l}\text { Ethiopia, Eritrea, Somalia, Djibouti, Sudan, other } \\
\text { African countries not included in "North Africa and the } \\
\text { Middle East" }\end{array}$ \\
\hline Iran & Non-West & Iran \\
\hline Iraq & Non-West & Iraq \\
\hline Turkey & Non-West & Turkey \\
\hline Asia & Non-West & Asia except the Middle East, Japan, Iran, Iraq, Turkey \\
\hline
\end{tabular}

Note: All groups are mutually exclusive.

Table A2 Share of self-employed with no employees, between 1 and 35 employees and more than 35 employees, per cent

\begin{tabular}{lccc}
\hline & Natives & $\begin{array}{c}\text { Western } \\
\text { immigrants }\end{array}$ & $\begin{array}{c}\text { Non-Western } \\
\text { immigrants }\end{array}$ \\
\hline No employees & 69.4 & 74.00 & 82.3 \\
Between 1 and 35 employees (sample used) & 30.2 & 25.7 & 17.7 \\
More than 35 employees & 0.5 & 0.3 & 0.1 \\
\hline Number of observations & 241527 & 24119 & 20033 \\
\hline
\end{tabular}


Table A3 Share of self-employed from different regions who only employ co-nationals, who employ at least one native, who employ at least one Western immigrant, and who employ at least one non-western immigrant

\begin{tabular}{|c|c|c|c|c|}
\hline $\begin{array}{l}\text { Self-employed }(\mathrm{N}=\text { native, } \mathrm{W}=\text { Western } \\
\text { immigrant, } \mathrm{NW}=\text { non-Western } \\
\text { immigrant) }\end{array}$ & $\begin{array}{l}\text { Share who } \\
\text { only } \\
\text { employ } \\
\text { workers } \\
\text { from the } \\
\text { same group } \\
(\%) \\
\end{array}$ & $\begin{array}{l}\text { Share who } \\
\text { employ at least } \\
\text { one native (\%) }\end{array}$ & $\begin{array}{c}\text { Share who } \\
\text { employ at least } \\
\text { one Western } \\
\text { immigrant (\%) }\end{array}$ & $\begin{array}{c}\text { Share who } \\
\text { employ at least } \\
\text { one non- } \\
\text { Western } \\
\text { immigrant (\%) }\end{array}$ \\
\hline \multicolumn{5}{|l|}{ One self-employed (All self-employed ${ }^{\mathrm{a}}$ ) } \\
\hline Sweden & 69.9 & 95.4 & 17.0 & 7.6 \\
\hline Nordic countries (W) & 11.3 & 80.2 & 39.8 & 10.6 \\
\hline EU-countries (EU12) (W) & 8.3 & 76.6 & 39.8 & 24.3 \\
\hline New EU-countries (NW) & 7.9 & 74.0 & 23.7 & 32.8 \\
\hline \multicolumn{5}{|l|}{ Eastern Europe and the former Soviet } \\
\hline Union (NW) & 31.3 & 47.4 & 14.5 & 63.7 \\
\hline USA, Canada, Japan and Oceania (W) & 1.9 & 85.4 & 28.5 & 10.6 \\
\hline South and Central America (NW) & 25.2 & 44.7 & 17.1 & 65.8 \\
\hline North Africa and the Middle East (NW) & 38.0 & 29.3 & 13.1 & 76.4 \\
\hline Africa (NW) & 17.8 & 56.3 & 14.6 & 54.2 \\
\hline Iran (NW) & 40.5 & 30.7 & 8.9 & 75.8 \\
\hline Iraq (NW) & 44.3 & 17.1 & 8.6 & 91.4 \\
\hline Turkey (NW) & 40.9 & 29.8 & 10.5 & 81.4 \\
\hline Asia (NW) & 36.4 & 46.5 & 13.8 & 67.9 \\
\hline \multicolumn{5}{|l|}{ More than one self-employed } \\
\hline $\begin{array}{l}\text { Two self-employed, } \\
\text { at least one Western immigrant }\end{array}$ & - & 88.8 & 41.7 & 15.3 \\
\hline $\begin{array}{l}\text { Two self-employed, at least one } \\
\text { is non-Western immigrant }\end{array}$ & - & 69.4 & 23.6 & 49.6 \\
\hline Two self-employed, no natives & - & 62.8 & 51.3 & 46.2 \\
\hline Two self-employed, no immigrants & - & 97.7 & 21.8 & 10.0 \\
\hline $\begin{array}{l}\text { More than two self-employed, at } \\
\text { least one is Western immigrant }\end{array}$ & - & 96.0 & 43.3 & 24.6 \\
\hline $\begin{array}{l}\text { More than two self-employed, at } \\
\text { least one is non-Western immigrant }\end{array}$ & - & 83.3 & 34.6 & 45.1 \\
\hline $\begin{array}{l}\text { More than two self-employed, no } \\
\text { natives }\end{array}$ & - & 88.8 & 48.9 & 56.4 \\
\hline $\begin{array}{l}\text { More than two self-employed, } \\
\text { no immigrants }\end{array}$ & - & 98.2 & 30.1 & 15.1 \\
\hline
\end{tabular}

\footnotetext{
${ }^{\mathrm{a}}$ The first column is calculated for all workplaces, independent of the number of self-employed. If all people who work at a certain workplace originate from the same country or region it means that all self-employed come from the same country or region.
} 
Table A4 Share who only employs co-nationals for some selected industries (\%)

\begin{tabular}{lccccc}
\hline Country of origin & All & Manufacturing & Construction & Retailing & Hotels and restaurants \\
\hline Sweden & 69.9 & 55.8 & 74.6 & 71.3 & 57.4 \\
Western immigrants & 10.0 & 8.5 & 12.6 & 7.8 & 11.4 \\
Non-Western immigrants & 29.1 & 14.9 & 10.8 & 27.0 & 41.7 \\
\hline
\end{tabular}

Table A5 Sample means for the self-employed, per cent

\begin{tabular}{|c|c|c|c|}
\hline & Natives & $\begin{array}{l}\text { Western } \\
\text { immigrants }\end{array}$ & $\begin{array}{c}\text { Non-Western } \\
\text { immigrants }\end{array}$ \\
\hline \multicolumn{4}{|l|}{ Age } \\
\hline Mean age (years) & 46.5 & 45.9 & 41.5 \\
\hline $20-30$ & 5.4 & 4.7 & 14.1 \\
\hline $31-40$ & 22.1 & 24.9 & 32.4 \\
\hline $41-50$ & 33.2 & 36.3 & 34.5 \\
\hline $51-60$ & 34.1 & 29.1 & 16.5 \\
\hline $60-64$ & 5.2 & 5.0 & 2.6 \\
\hline Women & 27.2 & 30.1 & 26.8 \\
\hline Married & 70.0 & 68.5 & 72.2 \\
\hline \multicolumn{4}{|l|}{ Education } \\
\hline Low education & 33.4 & 30.0 & 28.9 \\
\hline Intermediate education & 50.6 & 50.2 & 45.4 \\
\hline High education & 15.8 & 18.8 & 22.1 \\
\hline Missing information & 0.2 & 1.1 & 3.6 \\
\hline \multicolumn{4}{|l|}{ Place of residence } \\
\hline Stockholm & 11.8 & 24.5 & 33.0 \\
\hline Göteborg & 4.3 & 4.8 & 7.2 \\
\hline Malmö & 3.9 & 4.1 & 7.8 \\
\hline Number of employees & 4.5 & 4.2 & 2.9 \\
\hline \multicolumn{4}{|l|}{ Start year of the firm } \\
\hline 1985 or earlier & 40.8 & 31.9 & 20.0 \\
\hline 1986-1989 & 22.3 & 23.9 & 18.8 \\
\hline 1990-1994 & 24.5 & 29.2 & 29.9 \\
\hline $1995-1998$ & 12.4 & 15.1 & 32.0 \\
\hline \multicolumn{4}{|l|}{$\begin{array}{l}\text { Number of self-employed } \\
\text { (employers) }\end{array}$} \\
\hline One employer & 43.7 & 48.6 & 61.2 \\
\hline Two employers & 39.1 & 38.4 & 30.4 \\
\hline More than two employers & 17.2 & 13.1 & 8.5 \\
\hline \multicolumn{4}{|l|}{ Industry } \\
\hline Manufacturing & 16.5 & 17.0 & 9.1 \\
\hline Agriculture and fishing & 9.0 & 4.9 & 1.2 \\
\hline Construction & 15.2 & 13.2 & 3.1 \\
\hline Retailing & 28.0 & 25.7 & 22.0 \\
\hline Hotels and restaurants & 3.1 & 8.6 & 33.6 \\
\hline Transport & 9.9 & 7.6 & 10.6 \\
\hline Financial services & 0.2 & 0.3 & 0.1 \\
\hline Industrial services & 11.8 & 14.4 & 10.2 \\
\hline Education & 0.7 & 0.9 & 0.3 \\
\hline Health care & 2.4 & 3.5 & 4.6 \\
\hline
\end{tabular}




\begin{tabular}{|c|c|c|c|}
\hline Other social services & 2.9 & 3.5 & 4.4 \\
\hline Unknown & 0.3 & 0.5 & 0.9 \\
\hline \multicolumn{4}{|l|}{ Number of years in Sweden } \\
\hline Born in Sweden & & 44.2 & 15.1 \\
\hline \multicolumn{4}{|l|}{ Birth region } \\
\hline The Nordic countries & & 67.9 & \\
\hline EU12 & & 27.8 & \\
\hline $\begin{array}{l}\text { USA, Canada, Australia } \\
\text { and Japan }\end{array}$ & & 4.3 & \\
\hline Asia & & & 11.7 \\
\hline New EU-countries & & & 24.5 \\
\hline $\begin{array}{l}\text { Eastern Europe and the } \\
\text { former Soviet Union }\end{array}$ & & & 19.4 \\
\hline South and Central America & & & 3.4 \\
\hline $\begin{array}{l}\text { North Africa and the Middle } \\
\text { East }\end{array}$ & & & 12.0 \\
\hline Africa & & & 2.1 \\
\hline Iran & & & 8.3 \\
\hline Iraq & & & 2.5 \\
\hline Turkey & & & 16.2 \\
\hline \multicolumn{4}{|l|}{ Dependent variables } \\
\hline $\begin{array}{l}\text { Only employ workers from } \\
\text { the same region }\end{array}$ & 69.9 & 10.1 & 29.1 \\
\hline Employ at least one native & 96.6 & 83.4 & 51.7 \\
\hline $\begin{array}{l}\text { Employ at least one Western } \\
\text { immigrant }\end{array}$ & 21.7 & 42.6 & 18.7 \\
\hline $\begin{array}{l}\text { Employ at least one non- } \\
\text { Western immigrant }\end{array}$ & 10.3 & 17.0 & 62.4 \\
\hline Observations & 72829 & 6190 & 3535 \\
\hline
\end{tabular}

